\title{
Introduction
}

The purpose of this volume is to contribute to the cartographic calculations for the poleis which appear in Ptolemy regarding Dacia, in the effort to reach a better representation of Dacia, in general, and of the Roman province of Dacia, in particular. ${ }^{1}$ The calculations done by others and the studies that I am aware of will be included in the volume.

As a member of the Balkan History Association, and author of several articles in its Hiperboreea Journal, I was honoured to receive the support to pursue this subject from the Association. The main purpose of this study is not to argue on any historical or archaeological grounds, but rather to estimate positions and do the calculations and only afterwards find possible archaeological matches.

Some of the poleis will be taken as references, since they are already clearly established. This is the case of Porolissum, for instance, for the northern array of the Ptolemaic poleis in Dacia.

I consider this study preliminary because the Ptolemaic values need much further attention, more than I can propose here. This book represents a necessary starting point for possible future debates, which will strengthen or, on the contrary, will question some paths opened here.

Mapping a region of the Ptolemaic map in modern coordinates is a difficult task. The local patterns can suffer secondary alterations, as already acknowledged by other studies. ${ }^{2}$ The map of Ptolemy gathers

${ }^{1}$ Csaba Szabó, "The Map of Roman Dacia in the Recent Studies," Journal of Ancient History and Archeology 1 (2014): 44-51.

2 A. Stückelberger et al., Claudius Ptolemaens' Handbook of Geography (Basel: Schwabe Verlag, 2009). Evangelos Livieratos, Angeliki Tsorlini, and Chryssoula Boutoura, "Coordinate analysis of Ptolemy's Geographia Europe Tabula X with respect to geographic graticule and point positioning in a Ptolemaic late $15^{\text {th }}$ century map," e-Perimetron, Vol. 2, No. 2, Spring, 2007, 80-91, accessed May 7, 2018, https://www.researchgate.net/publication/266242744_Coordinate_analysis_o f_Ptolemy's_Geographia_Europe_Tabula_X_with_respect_to_geographic_gra ticule_and_point_positioning_in_a_Ptolemaic_late_15_th_century_map. C. 
regional "patches,"3 so we need to approximate a suitable framework for Dacia, and find reasonable solutions. This is what I am trying to do in this study, for Dacia, in conjunction with some relevant neighbouring areas, such as the southern bank of the Danube, and some locations east of Dacia proper. This study will not reject, but invite further discussions. The strongest results in the study include, however, some remarkable matches with the archaological evidences.

I thank Mihai Dragnea, the Balkan History Association, and the editors of the Hiperboreea Journal for their guidings and support, which made possible the publication of this book.

\section{The Author}

Marx, "On the precision of Ptolemy's geographic coordinates in his Geographike Hyphegesis," History of Geo- and Space Sciences 2(1) Copernicus Publications (2011): 2937, http://www.hist-geo-space-sci.net/2/29/2011/hgss-2-29-2011.html. Marx, "Rectification of the ancient geographic coordinates in Ptolemy's Geographike Hyphegesis," History of Geo- and Space Sciences 3(1) Copernicus Publications (2012): 99-112, http://www.hist-geo-space-sci.net/3/99/2012/hgss-3-992012.pdf. Sorin Forțiu, "The Translation of the Ptolemaic Coordinates into Modern Coordinates. Case Study: Zurobara," presented at the Symposium Culture and Civilisation in the Historical Banat, $21^{\text {st }}$ ed., Section "Arheologie şi istorie veche," 26.05.2011. Forțiu, "Geodetic-Statistical Analysis, just a classical GIGO?!," ArbeoVest, no. 1, In Memoriam Liviu Măruia, Interdisciplinaritate in Arheologie și Istorie, Timişoara, 7 december, 2013, Vol. II, 617-643, http://arheovest.com/simpozion/arheovest1/38_617_643.pdf. I. Tupikova and K. Geus, The Circumference of the Earth and Ptolemy's World Map (Dresden \& Berlin: Max Planck Institute for the History of Science, 2013).

${ }^{3} \mathrm{~J}$. Lennart Berggren and Alexander Jones, Ptolemy's Geography: An Annotated Translation of the Theoretical Chapters (Princeton and Oxford: Princeton University Press, 2000). R. Darcy and W. Flynn, "Ptolemy's map of Ireland: a modern decoding," Irish Geography 41(1) (2008): 49-69, doi: 10.1080/00750770801909375, https://www.researchgate.net/publication/233191569_Ptolemy's_map_of_Ire land_A_modern_decoding. Abshire Corey et al., "Ptolemy's Britain and Ireland: A New Digital Reconstruction," in Proceedings of the 2017 International Cartographic Conference, Washington D.C., 2017, accessed 07.03.2019, 2:42 p.m., http://pervokarta.ru/wash.pdf. C. Marx and F. Neitzel. "Deformation analysis and regional adaptation of a historical geodata inventory," in Entwicklerforum Geoinformationstechnik, Junge Wissenschaftler forschen (Aachen: Shaker Verlag, 2007), 243-255. 